different nations conceal substantial fluctuations; in cities the number of people per square kilometre may be greater than in rural areas by several orders of magnitude. It seems reasonable to suppose that bigger nations will support bigger conurbations than small, and that hence the mean population density for a large nation may be greater than for smaller ones. If this were so, then nations of similar character might fall into alignment on a graph of $\log$ population density on log nation size (Fig.1). They would also give apparently meaningful alignments in graphs of log nation size $(W)$ on log area $(=1 / N)$ (ref. 6). In particular, if the slope of the graph of log population density $(=W . N)$ on $\log$ nation size $(=W)$ is approximately $1 / 3$, then the slope of the graph of log nation size $(W)$ on log area $(=$ $1 / N$ ) will be approximately $3 / 2$; but this does not mean that people obey the same 'laws' of nature as plants. The alignments, I suggest, are attributable to the factors that control the aggregation of people in cities and not to any inherent tendency for the nation states within a continent to undergo 'self-thinning'.

RICHARD C. HARDWICK National Vegetable Research Station,

Wellesbourne,

Warwick CV35 9EF, UK

1. Tadaki, Y. \& Shidei, T. Nippon Rin Gakkaishi 41, 341-349 (1959)

2. Yoda, K., Kira, T., Ogawa, H. \& Hozumi, K. J. Inst. Polytech. Osaka City Univ. 14, 107-129 (1963).

4. Westoby, M. Adv. Ecol. Res. 14, 167-225 (1984)

5. Denness, B. Nature 320, 491 (1986).

6. Hayton, A. F. Nature 310, 178 (1984).

\section{Is Classic Coca-Cola the real thing?}

SIR-During 1985, the Coca-Cola Company discontinued production of its "old" Cola-Cola soft drink and introduced the New Coca-Cola. In response to public demand for the "old" Coke, the CocaCola Company began marketing the Classic Coca-Cola. Consumer complaints about difference in taste between the Classic and "old" version were supported by claims from both the Sugar Association, Inc. ${ }^{1}$ and Newsweek ${ }^{2}$ that the CocaCola Company had discontinued the use
3. Gorham, E. Nature 279, 148-150 (1979).

of sucrose (table sugar) in 1984. Since the Classic Coca-Cola container bears the words "Original Formula" and the major ingredient other than carbonated water in both the Classic and the New Coca-Cola is "high fructose corn syrup and/or sucrose", while that of "old" Coca-Cola was "sugar", we determined the sugar content of the newly introduced drinks to compare them with our previous analyses of "old" Coca-Cola.

Sugar analyses, using a gas-liquid chromatographic procedure ${ }^{3}$, confirm claims ${ }^{1.2}$ that neither Classic nor New Coca-Cola contain sucrose, whereas in 1983 we found that "old" Coca-Cola contained $4.7 \%$ sucrose (Table 1). There was also no sucrose in what we refer to as "transition" Coke since it was produced just prior to the introduction of the New Coca-Cola on 23 April 1985. Total sugar content of "transition", Classic and "old" Coca-Cola was very similar, but the new version contains about $10 \%$ more total sugars than any of the others.

As noted above, the Coca-Cola labels now read "high fructose corn syrup and/or sucrose", thus eliminating the use of the word "sugar". Recently the cereal industry made a similar move by eliminating the word "sugar" from the name of cereals and from its advertising even though the product and the sugar content remained unchanged ${ }^{4}$. Why discontinue the use of the word "sugar" which most consumers understand to be table sugar? Because health conscious consumers often associate sugar with obesity, diabetes mellitus, heart disease and dental caries ${ }^{5}$.

Sucrose (table sugar) has long been considered the mortal enemy of the teeth by virtue of the amount ingested and its pattern of use ${ }^{6}$. What impact upon dental health should one expect from the replacement of sucrose with fructose and glucose in soft drinks? Such an assessment is impossible at the present time because there are no definitive studies which demonstrate clearly the contribution of sucrose, fructose, or glucose in soft drinks to incidence of dental caries.

If sucrose is the arch criminal of dental caries as has been claimed ${ }^{7}$, one might expect a decrease in the incidence of

Table 1 Sugar analysis of Coca-Cola by gas-liquid chromatography

\begin{tabular}{|c|c|c|c|c|c|c|}
\hline \multirow[b]{2}{*}{$\begin{array}{l}\text { Product } \\
\text { (code) }\end{array}$} & \multirow[b]{2}{*}{$\begin{array}{l}\text { Date of } \\
\text { production }\end{array}$} & \multirow[b]{2}{*}{$\begin{array}{l}\text { Date of } \\
\text { analysis }\end{array}$} & \multicolumn{4}{|c|}{ Sugar content $(\%)$} \\
\hline & & & Fructose & Glucose & Sucrose & Total \\
\hline $\begin{array}{l}\text { "Old" } \\
(032483289)\end{array}$ & 24 Mar. '83 & 12 Apr. '83 & $3.3 \pm 0.1$ & $2.9 \pm 0.3$ & $4.7 \pm 0.3$ & 10.9 \\
\hline $\begin{array}{l}\text { "Transition" } \\
\text { (no code) }\end{array}$ & $\begin{array}{l}\text { Early } 1985 \\
\text { before } 23 \text { Apr. ' } 85\end{array}$ & 13 Sept. ' 85 & $6.3 \pm 0.1$ & $4.5 \pm 0.1$ & 0 & 10.8 \\
\hline $\begin{array}{l}\text { New Coca-Cola } \\
(061485189)\end{array}$ & 14 June ' 85 & 13 Sept. ' 85 & $7.0 \pm 0.1$ & $4.9 \pm 0.1$ & 0 & 11.9 \\
\hline $\begin{array}{l}\text { Classic Coca-Cola } \\
(\mathrm{K} 8 \mathrm{H} 22)\end{array}$ & 22 Aug. ' 85 & 13 Sept. '85 & $6.3 \pm 0.1$ & $4.6 \pm 0.1$ & 0 & 10.9 \\
\hline
\end{tabular}

Sugar contents are mean \pm standard deviation of triplicate determinations. dental caries due to the elimination of sucrose from the soft drinks. However, if fructose and glucose are as cariogenic as sucrose in soft drinks, one might expect an increase in the incidence of dental caries due to an increased amount of total sugar as seen in the New Coca-Cola. What effect, if any, the changes will have on consumer demand and/or health remains to be seen.

This work was supported by Veterans Administration Research Service. We thank R.W. Christensen and H.V. Nguyen for technical assistance and D.M. Larson for secretarial assistance.

LEIGH E. WYBORNY

Ira L. SHANNON

Oral Disease Research Laboratory,

Veterans Administration Medical Center,

Houston, Texas 77211, USA

and

Department of Biochemistry,

University of Texas Dental Branch,

Houston, Texas 77225, USA

1. The Sugar Association, Inc. The Houston Post, 7B (15 August, 1985)

2. Newsweek, 54-55 (26 August, 1985).

3. Li, B. W. \& Schuhmann, P.J. J. Food Sci. 45, 138-141 (1980).

4. Liebman, B. Nutr. Action 12, 10-11 (Jul/Aug 1985).

5. Shannon, I.L. Brand Name Guide to Sugar (Nelson-Hall. Chicago, 1977).

6. Shannon, I.L. Amer. Chirop. 1, $54-57$ (1978).

7. Newburn, E. Odont. Rev. 18, 373-386 (1967)

\section{Are we all}

\section{out of Africa?}

SIR-Additional information on world population distributions of human marker genes, such as that provided by Wainscoat et al.' for five closely linked polymorphic restriction enzyme sites in the $\beta$-globin gene cluster, is always welcome. One must agree, on the basis of the restriction enzyme evidence provided, that there is a clear distinction between African and Eurasian populations, an opinion in accord with at least some other genetic studies. While Wainscoat et al. are nominally cautious about a second proposition, stating that their data are "consistent with" the notion that anatomically modern man (Homo sapiens sapiens) arose in Africa and subsequently spread to Eurasia and the Americas, it is difficult to deny that their results will be taken as "new evidence that the origin of modern man lies in Africa"

A close scrutiny of this new evidence is especially important because of its potential value when the prime archaeological rationale for asserting great antiquity for South African $H$. s. sapiens at Klasies River Mouth and Border Cave is not conclusive $^{3,4}$, has been challenged ${ }^{5}$, and the $H$. s. sapiens status of the Omo specimens from Ethiopia has been questioned ${ }^{6}$.

On the basis of a sample perhaps more limited than the authors concede, Wainscoat et al. note that three haplotypes (the specific sequence of appearance [+] or 